\title{
COMMUNICATION
}

\section{Giant Ekstra Bintaro Membangun Kesadaran Merek Produk UMKM Melalui Strategi Komunikasi Pemasaran Terpadu}

\author{
Taufan Prahara Gunadi \\ Universitas Budi Luhur \\ Email: taufan.prahara@budiluhur.ac.id \\ Jl. Ciledug Raya, Petukangan Utara, Jakarta Selatan, 12260. DKI Jakarta, Indonesia. \\ Telp: 021-585 3753 Fax: 021-585 3752
}

Submitted: 6 August 2019 Revised: 9 October 2019 Accepted: 11 October 2019

\begin{abstract}
ABSTRAK
Giant Ekstra Bintaro memiliki ko mitmen untuk mengembangkan produk lokal dengan cara menerima dan memasarkan produk UMKM diberbagai gerai yang tersebar luas di Indonesia. Karena selama ini pemasaran menjadi kendala bagi pengusaha kecil dan menengah dalam mengembangkan usaha. Hal yang dilakukan Giant Ekstra Bintaro adalah melakukan kegiatan promosi dalam membangun kesadaran merek atau keberadaan merek dalam ingatan konsumen untuk produk UMKM, dengan tujuan membedakan produk satu dengan produk lain atau produk pesaing. Dengan kesadaran merek yang tinggi memungkinkan Giant Ekstra Bintaro untuk meningkatkan penjualan atas produk makanan UMKM khususnya kategori fresh dan snack. Penelitian ini bertujuan untuk mengetahui serangkaian kegiatan pemasaran yang dilakukan Giant Ekstra Bintaro untuk produk UMKM. Metode yang digunakan adalah deksriptif kualitatif dengan melakukan indept interview kepada beberapa informan perusahaan dan para pengunjung Giant Ekstra Bintaro sektor 7 Tangerang Selatan. Dari hasil penelitian yang telah dilakukan dapat disimpulkan bahwa Giant Ekstra Bintaro sektor 7 Tangerang Selatan telah menerapkan komunikasi pemasaran terpadu untuk kegiatan pemasaran dan memperlakukan produk UMKM sama dengan produk reguler lainnya. Namun karena keterbatasan dana pihak supplier UMKM tidak bisa mengikuti semua kegiatan pemasaran yang diadakan sehingga brand awareness yang dihasilkan berada pada unaware brand, karena pengunjung lebih dominan membeli kebutuhan pokok dengan harga murah atau potongan harga tanpa mengetahui produk tersebut merupakan produk UMKM.
\end{abstract}

Kata kunci: brand awarenes, komunikasi pemasaran terpadu, UMKM

\begin{abstract}
Giant Ekstra Bintaro is committed to developing local products by accepting and marketing UMKM products in various outlets that are widespread in many cities in Indonesia. Because all this time marketing has become a plan for small and medium entrepreneurs in developing businesses. What is done by Giant Extra Bintaro is conducting promotional activities in building brand awareness or approving brands in consumers' memories for UMKM products, with the aim of determining one product with another product or competitive product. With high brand awareness, Giant Extra Bintaro to increase sales of UMKM food products specifically for fresh and snack categories. This study aims to determine a series of marketing activities carried out by Giant Extra Bintaro for UMKM products. The method of analysis used qualitative description independent interview to several informants inside the company and of course to the customer itself. Based on result of analysis, it can be concluded that Giant Ekstra binatro sektor 7 Tangerang Selatan has applied Integrated Marketing Communication for their marketing activity and also treat UMKM's product same like the regular one. However, because of the limited funds the UMKM's suppliers can not fully participate to the marketing activities. Finnaly unaware brand has resuited because the customers prefer to buy daily needs product in the cheaper or discount prices without knowing wether it's the UMKM product or not.
\end{abstract}

Keywords : brand awareness, integrated marketing communication, UMKM 


\section{PENDAHULUAN}

Giant Ekstra dimanapun berada selalu diperkuat dengan komunitas lokal. Juga memberikan kesempatan kepada pihak-pihak tersebut. Upaya itu dilakukan agar dimana sebuah gerai Giant Ekstra dibuka, kesempatan lapangan kerja dapat diberikan kepada penduduk lokal. Selain itu, dengan menjual beranekaragam usaha di gerai Giant Ekstra yang dilakukan oleh para pedagang kecil dan pedagang jalanan termasuk kue tradisional, makanan dan minuman ringan. Para pedagang kecil ini termasuk dalam Usaha Mikro Kecil Menengah (UMKM) yang telah menjadi bagian kesatuan dari gerai Giant Ekstra.

Tujuan dari kerjasama yang saling menguntungkan ini termasuk salah satu cara untuk meningkatkan keahlian pedagang kecil, perbaikan mutu barang, penyediaan sarana ke pasar dan pengembangan sumber daya manusia sehingga mampu membantu program pemerintah dalam memajukan UMKM dan memberikan penyedia sarana pemasaran. Dalam perjalanan bisnis eceran modern ini, Giant Ekstra memiliki saingan yang banyak yaitu Carrefour, Superindo, dan LotteMart yang memiliki format yang beragam, seperti minimarket, supermarket dan hypermarket dan berbagai format lainya guna untuk menarik konsumen.

Dalam persaingan yang ketat ini, maka sangat diperlukan strategi pemasaran perusahaan dalam mempertahankan kelangsungan hidup perusahaannya.

Pemasaran mempengaruhi secara langsung terhadap kelancaran maupun keberhasilan perusahaan dalam mencapai tujuannya. Dengan strategi pemasaran tepat dan sesuai maka produk akan mudah diterima calon konsumen sehingga calon konsumen membeli produk yang akan dijual.

Seiring perkembangan zaman, inovasi dan kreativitas dalam pengembangan strategi komunikasi pemasaran menjadi strategi komunikasi pemasaran terpadu yang membantu mengidentifikasi metode yang paling tepat dan efektif dalam berkomunikasi dalam menginformasikan, membujuk dan mengingatkan konsumen secara langsung maupun tidak langsung tentang produk dan merek yang ditawarkan. Giant Ekstra telah menerapkan strategi komunikasi terpadu dalam strategi pemasarannya yang bertujuan untuk mengenalkan berbagai produk sehingga para konsumen menyadari berbagai merek produk yang dipasarkan sehingga dapat meningkatkan hasil penjualan untuk mendapatkan laba.

Kotler \& Armstrong, menyatakan bahwa komunikasi pemasaran terpadu (Integrated Marketing Communications/IMC) yang biasa disebut bauran promosi (marketing mix) sebuah perusahaan terdiri dari perpaduan khusus antara pemasangan iklan, penjualan personal, promosi penjualan, hubungan masyarakat, dan pemasaran langsung yang digunakan perusahaan untuk mencapai tujuan-tujuan pemasangan iklan dan pemasaran (Kotler dan Armstrong, 2004:600-601). Hal ini dilakukan karena 
perusahaan dituntut untuk berkompetisi agar tetap bertahan dan terus bersaing memperluas pangsa pasar maupun jaringan distribusi yang perusahaan tersebut lakukan, diantaranya adalah memperbaiki kinerja, penerapan strategi pemasaran serta perbaikan pelayanan terhadap konsumen (Aulia Asa Robbika, 2016).

Dari hasil penelitian sebelumnya, bauran pemasaran yang mencakup produk, harga, distribusi, dan promosi pada bisnis ritel ini ditemukan dapat mempengaruhi kepuasan dan loyalitas pelanggan (Harald, 1993). Apabila kepuasan pelanggan terwujud, maka loyalitas terhadap perusahaan ritel juga akan terwujud, karena loyalitas yang ditekankan terhadap perusahaan ritel merupakan faktor penting dalam kesuksesan pedagang eceran dan kemampuan tempat perbelanjaan tersebut dalam bertahan (A. Surya, 2009).

Pentingnya strategi pemasaran untuk peningkatan pengenalan produk UMKM agar dikenal dan dibeli oleh konsumen, karena pembelian konsumen itu hal yang unik terkait dengan preferensi setiap orang terhadap suatu produk yang berbeda-beda dipengaruhi oleh banyak faktor diantaranya potongan harga, citra merek, dan servicescape (lingkungan fisik) (Monigir, 2016). Dan hal ini dilakukan agar mampu bersaing dengan kompetitor lain. Dengan menjalankan promosi yang sesuai dan efektif, usaha yang dijalankan akan lebih dikenal kepada masyarakat luas, mendatangkan konsumen dan mempertahankan konsumen loyal (Fildzah, 2018).

Produk UMKM di Giant Ekstra diperlakukan sama dalam hal pemasaran dan tidak dikenakan biaya besar sehingga membantu meningkatkan penjualan, juga sekaligus membangun brandawareness dengan mengenalkan produk UMKM sehingga para pelanggan mengetahui dan mengenali merek produk UMKM yang ada di Giant Ekstra demi menimbulkan minat beli terhadap produk UMKM tersebut. Minat beli pada konsumen merupakan sikap yang muncul sebagai tanggapan terhadap objek yang menandakan ketertarikan atau keinginan konsumen membeli suatu produk (Silaningsih dan Putami, 2018). Namun setiap supplier UMKM memiliki modal terbatas, sehingga belum bisa mengikuti semua fasilitas pemasaran. Konsekuensi mengikuti semua strategi komunikasi pemasaran terpadu, para supplier produk UMKM harus siap dengan jumlah produksi yang akan dipasarkan, bahan baku yang diperlukan, tepat waktu dalam pemesanan/refill sesuai permintaan.

Berikut merupakan ruang lingkup pembahasan komunikasi pemasaran terpadu sesuai teori yang dibuat oleh Kotler dan Armstrong: 


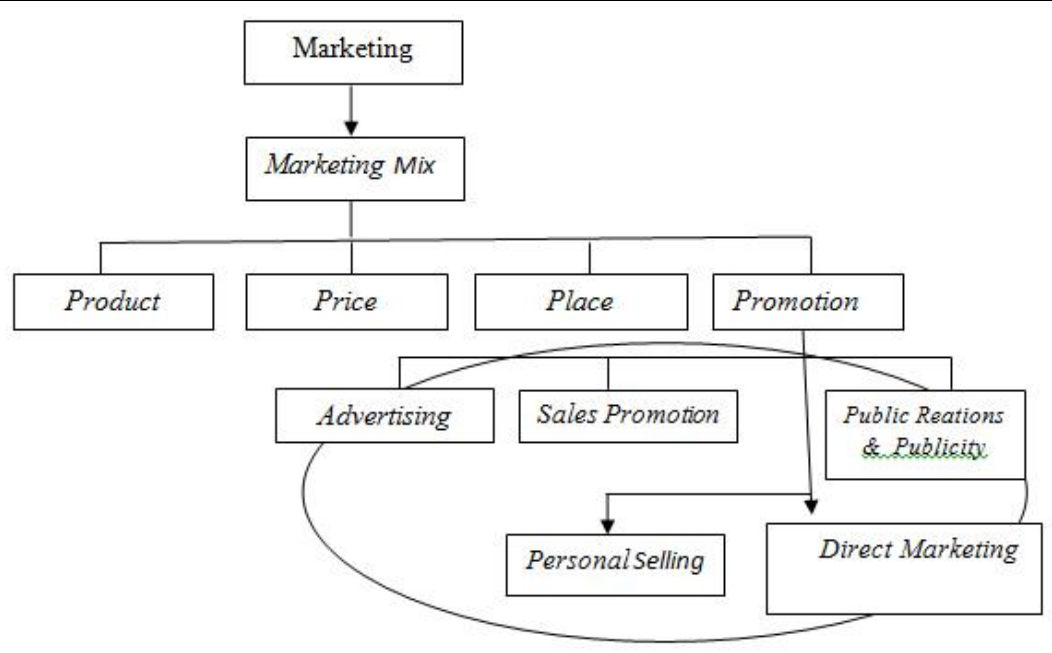

(Sumber : Philip Kotler \& Gery Armstrong. Dasar-dasar pemasaran jilid 2. Jakarta: Penerbit Erlangga (2001:200)

\section{Gambar 1 : Ruang Lingkup Komunikasi Pemasaran Terpadu}

Dengan melihat pembahasan tersebut peneliti memiliki tujuan untuk mengetahui strategi komunikasi pemasaran terpadu yang dilakukan di Giant Ektra Bintaro Sektor 7 Tangerang Selatan dalam membangun kesadaran merek terhadap produk UMKM, khususnya kategori fresh dan snack Selain teori pemasaran terpadu, peneliti menggunakan Teori kendali Organisasi Philip Tompkins, George Cheney, dan rekan-rekan yang mengembangkan sebuah pendekatan yang baru dan berguna terhadap komunikasi organisasi, dalam cara-cara komunikasi biasa membentuk kendali atas pegawai. Kendali dinyatakan dalam organisasi dengan empat cara. Kendali sederhana (simple control), kendali teknis, (technical control), birokrasi, kendali konsertif (concertive control), penggunaan hubungan interpersonal dan kerja sama tim sebagai sebuah cara kendali. Dalam organisasi konsertif, aturan dan regulasi yang tertulis jelas digantikan oleh pemahaman pemaknaan nilai, objektif, dan cara-cara pencapaian bersama, sejalan dengan apresiasi yang mendalam untuk "misi" organisasi.

Strategi-strategi pemasaran yang diterapkan diharapkan dapat membangun kesadaran merek atas produk UMKM tersebut. Kesadaran merek itu sendiri membutuhkan jangkauan kontinum (continum ranging) dari perasaan yang tak pasti bahwa merek tertentu dikenal, menjadi sebuah keyakinan bahwa produk tersebut merupakan satu-satunya dalam kelas produk bersangkutan (Aaker, 1997:92). Pengkajian hasil pembahasan kesadaran merek ini dapat 
merek, seperti yang ditunjukan dibawah ini:

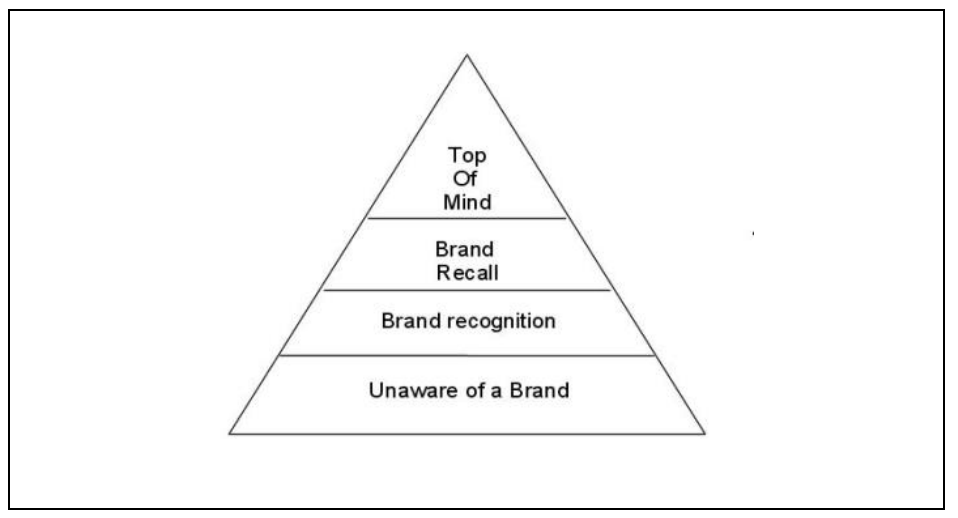

Sumber: Aaker (1997:92)

\section{Gambar 2 : Piramida Brand awareness}

Menurut Aeker, (1997:61) yang bagian dari suatu kategori produk adalah dikutip dari buku Agus Hermawan (2012:57), brand awareness adalah kemampuan dari seseorang yang merupakan calon pembeli (potential buyer) untuk mengenali (recognize) atau menyebutkan kembali (recall) suatu merek merupakan bagian dari kategori produk. Kesadaran merek merupakan pintu gerbang pertama untuk mengambil keputusan.

Dari pemaparan tersebut, maka alur kerangka pemikiran dapat penulis gambarkan sebagai berikut: 


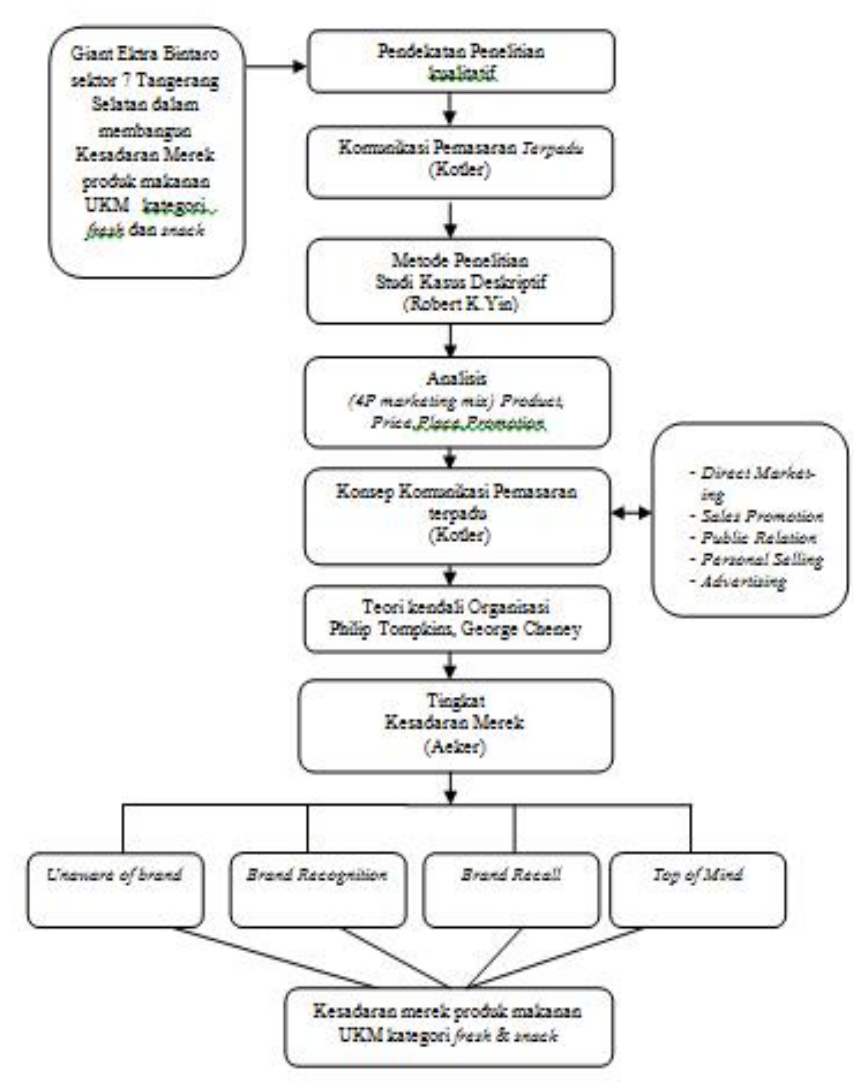

Gambar 3:

Alur Kerangka Pemikiran Giant Ekstra Bintaro sektor 7 Tangerang Selatan Dalam membangun Kesadaran merek Produk makanan UMKM kategori fresh dan snack

\section{METODE PENELITIAN}

Penelitian ini menggunakan paradigma postpositivisme karena ingin mengungkap fakta secara nyata mengingat perkembangan persaingan dalam bidang perdagangan dalam era globalisasi ini, dan untuk memperoleh gambaran yang lebih mendalam dan holistik mengenai Komunikasi Giant Ekstra Bintaro sektor 7 Selatan Dalam membangun Kesadaran Merek Produk UMKM kategori fresh dan snack dengan pengamatan langsung dan juga pengumpulan data, dengan cara berinteraksi. Paradigma adalah suatu cara pandang untuk memahami kompleksitas dunia nyata Paradigma menurut Bogdan dan
Biklen dalam Moleong mendefinisikan, kumpulan longgar dari sejumlah asumsi yang dipegang bersama. (Moleong, 2002:32). Menurut Nasution (dalam Ruslan, 2006:126) post-positivisme mencoba memperoleh gambaran yang lebih mendalam dan holistik, memandang peristiwa secara keseluruhan dalam konteksnya dan mencoba memperoleh pemahaman yang holistik. Selain itu, pospositivisme juga memahami makna suatu permasalahan, dan memandang hasil penelitian sebagai kegiatan bersifat spekulatif.

Penulis menggunakan pendekatan penelitian kualitatif dengan menggunakan 
metode kualitatif yaitu pengamatan, wawancara, atau penelaahan dokumen. Penulis menggunakan pendekatan deskriptif yaitu penulis mencoba menguraikan, dan menjelaskan serta menjabarkan mengenai komunikasi pemasaran terpadu Giant Ekstra Bintaro sektor 7 Tangerang Selatan Dalam membangun Kesadaran Merek Produk makanan UMKM kategori fresh dan snack. dengan menggunakan berbagai sumber data (sebanyak mungkin data) yang digunakan untuk penelitian seperti wawancara mendalam, observasi, partisipan, dokumentasi-dokumentasi, rekaman, buktibukti fisik, secara holistik.

Subjek penelitian ini peneliti menggunakan Informan sebagai pemasok informasi untuk memberi penjelasan kepada peneliti selengkap mungkin dengan cara: (1) melalui keterangan orang yang berwenang, baik secara formal maupun informal. (2) melalui wawancara mendalam yang dilakukan oleh peneliti, yaitu informan terdiri dari 4 karyawan dan pengunjung Giant Ekstra Bintaro sektor 7 Tangerang Selatan yang sedang berbelanja. Penelitian ini dilaksanakan pada Kantor pusat PT. Hero Supermaket Tbk dan Giant Ekstra cabang Bintaro beralamat di CBD Bintaro Sektor 7 Blok B7 /A7 Pondok Karya, Pondok Aren Tangerang Selatan 15224-Indonesia. Metode Pengumpulan Data. Dalam penelitian ini penulis menggunakan dua sumber data, yaitu data primer dan data sekunder.

\section{HASIL DAN PEMBAHASAN}

Giant Ekstra didirikan pada tanggal 26 Juli 2002, dan pertama kali dibuka di Villa Melati Mas, Serpong-Tangerang. Giant
Ekstra dengan mottonya "banyak pilihan harga lebih murah" dan diperkuat dengan operating phlylosopy "garansi harga murah setiap hari". Pada akhir 2018, HERO mengelola 445 gerai. Jumlah tersebut terdiri atas 270 gerai Guardian, 82 gerai Giant Ekspres, 57 Giant Ekstra, 32 gerai Hero Supermarket, 3 gerai Giant Mart dan 1 gerai IKEA.

Giant Ekstra memberikan berbagai macam pilihan makanan segar, makanan kemasan dan produk lainnya bagi masyarakat kelas menengah Indonesia yang berasal dari supplier Perusahaan besar dan UMKM, yang menawarkan berbagai jenis produk, termasuk produk lokal yang diambil langsung dari UMKM sehingga mendorong para supplier UMKM untuk dapat memasok produk yang berkualitas sesuai standar yang diterapkan Giant Ekstra Bintaro. Sehingga dengan ini Giant Ekstra Bintaro telah membantu program pemerintah dengan ikut serta memasarkan produk lokal yang berasal dari supplier UMKM setempat.Giant Ekstra memiliki visi menjadi peritel terkemuka di Indonesia dalam segi penjualan dan penciptaan nilai panjang bagi pemegang saham dengan misinya adalah meningkatkan nilai investasi pemegang saham melalui keberhasilan komersial dengan menarik pelanggan dan meningkatkan daya saing yang mantap.

Sasaran atau market yang ingin diraih oleh Giant Ekstra Bintaro Sektor 7 Tangerang Selatan adalah level menengah kebawah yang mencari kebutuhan seharihari dengan menawarkan harga terendah. Kegiatan usaha Giant Ekstra Bintaro Sektor 
7 Tangerang Selatan menjalankan usaha retailing dalam berbagai bentuk, yaitu:

1. Food repacking, yaitu membungkus dalam kemasan kecil untuk berbagai kebutuhan pokok dan makanan kering.

2. Instore bakery, yaitu sarana pembuatan dan penjualan berbagai jenis roti dan kue.

3. Food processing yaitu sarana pembuatan berbagai makanan olahan baik setengah jadi maupun siap hidang langsung atau biasa disebut divisi Reat to Eat (RTE)

4. Fast food yaitu bagian counter makanan jepang, aneka sari buah dan juice, dimsum dan makanan siap saji lainnya.

Dalam kegiatan pemasaran, Giant Ekstra Bintaro telah menerapkan strategi komunikasi pemasaran baik untuk meningkatkan penjualan maupun membangun kesadaran merek semua produk yang dijual di Giant Ekstra termasuk produk UMKM. Divisi yang bertanggung-jawab dalam melaksanakan fungsi strategi komunikasi pemasaran terpadu meliputi divisi marketing (Ibu Linda), merchandising (Bapak Samuel), asisten manager toko (Ibu Henny), public relations (Ibu nafisyah). Perlakuan terhadap produk UMKM sama dengan produk reguler lainnya dalam kegiatan pemasaran dipersiapkan dengan baik hingga kontrol implementasi ke toko setelah kegiatan komunikasi pemasaran dijalankan.

Sebelum mengkaji pemasaran terpadu, peneliti mengkaji bauran pemasaran (marketing mix) terhadap produk UMKM terlebih dahulu, sebagai berikut:

\section{Bauran Produk}

Dalam analisa produk ini dibagi menjadi tiga pembahasan, yaitu jenis produk, pengemasan, proses masuknya barang dan jaminan produk.

a. Jenis dan Keanekaragaman Produk. Produk yang di tawarkan di Giant Ekstra khusus produk UMKM adalah food dan non food yaitu makanan ringan (snack), hasil laut, sayuran, buahbuahan, produk olahan, makanan beku, dan kebutuhan rumah tangga. Divisi kerja yang menangani produk UMKM sama dengan divisi kerja produk reguler. 
Produk UKM yang masuk Ke Giant Ekstra Bintaro Sektor 7

\begin{tabular}{|c|c|c|c|}
\hline Nomor & Nama Kategori & Jenis Produk & Contoh produk \\
\hline \multirow[t]{6}{*}{1} & Fresh & $\begin{array}{l}\text { - Makanan hasil } \\
\text { laut }\end{array}$ & $\begin{array}{l}\text { ikan gurame, ikan patin, } \\
\text { udang, cumi-cumi, kepiting, } \\
\text { ikan bandeng }\end{array}$ \\
\hline & & - Daging & daging ayam dan daging sapi \\
\hline & & - Sayuran & $\begin{array}{l}\text { kangkung akar, bayam hijau, } \\
\text { caysm, daun singkong, pakcoy } \\
\text { hijau, sawi putih, kol gopeng } \\
\text { putih, buncis, brocoli, tomat, } \\
\text { jagung acar, ketimun, labu } \\
\text { siam, wortel, jamur kuping, } \\
\text { kentang }\end{array}$ \\
\hline & & -Buah-buahan & $\begin{array}{l}\text { jeruk, semangka merah, salak } \\
\text { pondoh, alpukat, apel, } \\
\text { mangga, melon, pisang, buah } \\
\text { naga }\end{array}$ \\
\hline & & - Produk olahan & tahu, bakso, mie, sosis \\
\hline & & - Makanan beku & nudget, otak-otak curah \\
\hline 2 & Snack & makanan ringan & $\begin{array}{l}\text { kacang-kacangan, kue, bolu, } \\
\text { kerupuk, keripik singkong, } \\
\text { permen }\end{array}$ \\
\hline 3 & $\begin{array}{l}\text { Kebutuhan } \\
\text { rumah tangga }\end{array}$ & Perabotan & $\begin{array}{l}\text { panci, hanger baju, keset } \\
\text { anyam, lap, kain pel, anduk, } \\
\text { cetakan kue }\end{array}$ \\
\hline
\end{tabular}

b. Proses penerimaan produk UMKM.

Supplier UMKM dapat mendatangi langsung kantor Giant Ekstra Bintaro untuk mengurusi semua administrasi yang dibutuhkan dan melakukan korespondensi dengan pihak buyer setempat dalam menawarkan produknya. Kemudian pihak Giant Ekstra Bintaro Sektor 7 Tangerang Selatan akan memenuhi penawaran dengan mengkaji terlebih dahulu produk yang ditawarkan.

c. Pengemasan Produk UMKM.
Giant Ekstra tidak memberikan kriteria khusus, namun cenderung menyerahkan langsung kepada pihak UMKM.

d. Penjagaan Mutu Produk UMKM Produk UMKM harus dilengkapi dengan perizinan BPOM, karena setiap produk melalui proses quality control, jika ada produk yang memiliki kualitas buruk dikembalikan kepada supplier. Hal ini dilakukan untuk memastikan produk UMKM aman untuk dikonsumsi.

e. Garansi produk

Semua produk yang dijual di Giant Ekstra memiliki garansi 
produk, termasuk produk UMKM. Jaminan ini diwujudkan dalam berbagai bentuk, sebagai salah satu tanggungjawab kepada konsumen dengan tujuan untuk memuaskan para pelanggannya, diantaranya dirumuskan dalam bentuk sebagai berikut:
a. Ada yang lebih murah? Kami ganti selisihnya 3 kali!
b. Tidak puas? Kembalikan saja!

c. Harga kasir tidak sama harga di rak? Bayar yang termurah

d. Parkir gratis di beberapa lokasi gerai Giant Ekstra

e. Berbelanja dengan sistem kredit dari sumber kredit.

Produk UMKM selalu disortir untuk memisahkan produk yang sudah mendekati masa kadaluarsa untuk diberikan potongan harga sehingga tetap terjual dan tidak rugi.

2. Bauran harga

Meningkatkan daya saing (competitiveness) harga dengan menetapkan harga jual yang lebih rendah dari pesaing. Untuk produk UKM harga ditetapkan berdasarkan kesepakatan antara pihak supplier dengan Giant Ekstra Bintaro Sektor 7 Tangerang Selatan begitupun dengan margin keuntungan, sebisa mungkin harga yang diberikan terjangkau dengan kualitas yang baik.

3. Bauran tempat Mempertahankan lokasi bangunan dan counter penjualan yang telah ada, serta menjaga kontinyuitas pasokan produk baik dalam jenis dan kuantitasnya. Giant Ekstra Bintaro Sektor 7 Tangerang Selatan berada ditempat yang strategis dan counter penjualan untuk kategori fresh dan snack dibuat sama dengan produk reguler sehingga terdapat impulse buying. Kategori fresh diberikan logo dan stiker gambar yang menunjukkan jenis produknya, seperti gambar ikan, sayuran, buahbuahan, daging sehingga menarik dilihat. Untuk kategori snack, disimpan di rak gondola berdampingan dengan produk reguler dan raknya tersebut ditempatkan dengan produk makanan lainnya.

\section{Promosi}

Program promosi yang dilakukan untuk produk UMKM adalah potongan harga/discount untuk produk kategori fresh dan snack, mengadakan kegiatan demo masak atau icip-icip untuk kategori fresh (contohnya tahu yun-yi dan kacang edamame) dan bazar. Programprogram promosi terdiri dari:

a. Promosi murah abis

Promosi ini dipasang di koran Kompas setiap hari jumat dan promosi iklan tersebut berlaku selama tiga hari (weekend)

b. Promosi Pasar Segar

Promosi ini adalah media katalog yang berlangsung sepuluh hari. Semua item yang berada pada promosi katalog akan tercantum pada miller 
masing-masing produk yang menjadi promosi katalog di toko.

c. Instore Promo

Yaitu kegiatan promosi yang dilakukan dengan kebijakan toko. Hal yang dilakukan adalah dengan menggolongkan barang tersebut pada special price, menurunkan atau menaikkan harga produk berdasarkan permintaan dan stok, pendisplay-an, serta membuat promosi melalui mailer, poster, spanduk dan lainnya.

d. Midnight sale

Midnight sale diselenggarakan pada minggu terakhir diakhir bulan. Kegiatan promosi ini dipublikasikan di koran kompas. Kegiatan promosi akan berlangsung dari pukul 22.00 WIB hingga pukul $24.00 \mathrm{WiB}$.

e. Bazaar

$\begin{array}{lr}\text { Giant Ekstra } & \text { Bintaro } \\ \text { mengadakan } & \text { bazaar } \\ \text { dilingkungan toko atau diluar }\end{array}$

toko (area parkir) namun tidak semua produk UMKM mengikutinya, karena kegiatan bazaar membutuhkan dana yang tidak sedikit.

Tahapan berikutnya adalah pembahasan strategi komuikasi pemasaran terpadu yang dikaji adalah yaitu:

1. Pemasaran langsung (Direct Marketing) Jenis produk UMKM yang dipasarkan di Giant Ekstra Bintaro Sektor 7 Tangerang Selatan adalah snack, hasil laut, sayuran dan buah-buahan serta kerajinan tangan. Produk UMKM ini langsung dipajang untuk dipasarkan langsung ke konsumen. Selain itu, Giant Ekstra membuat katalog toko dan katalog online yang bisa langsung di download langsung oleh para konsumen dan memiliki situs resmi yang dapat diakses langsung para konsumennya yaitu di www.giant.co.id 

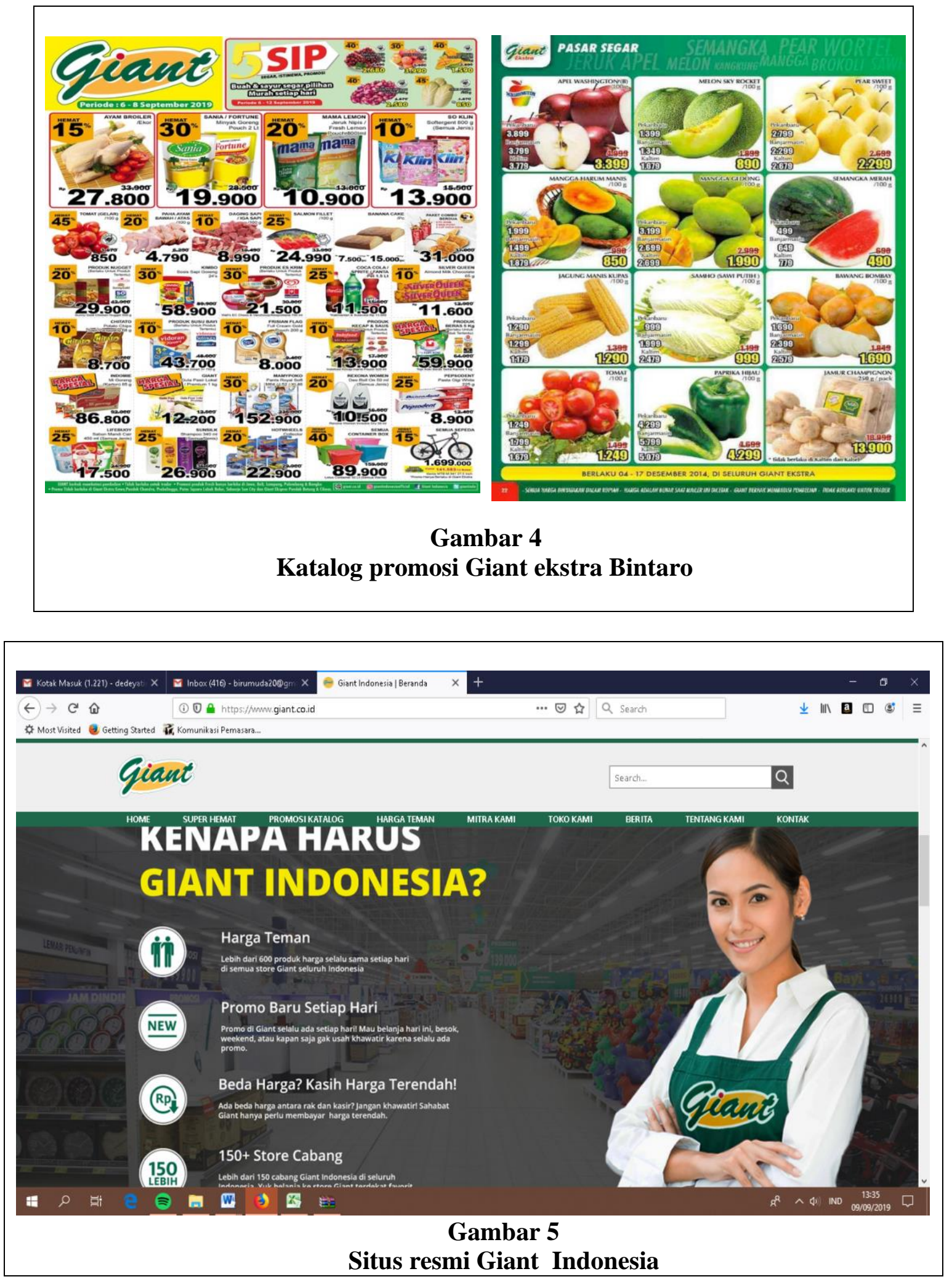
2. Promosi Penjualan (sales promotion)

Giant Ekstra Bintaro menggunakan teknik promosi penjualan bisnis ke konsumen (business to consumers-B2C), promosi penjualan bisnis ke bisnis (business to business-B2B) dan kesepakatan dagang. Secara rinci dijelaskan sebagai berikut:

1) Promosi penjualan bisnis ke konsumen (business to consumersB2C) terdiri dari potongan harga, kontes, sampel

2) Promosi penjualan bisnis ke bisnis (business to business-B2B) terdiri dari POP displays, pameran dagang, pertemuan tenaga penjual, pemenuhan pesanan, dan kesepakatan dagang

Berikut penjelasan mengenai potongan harga dan tester produk:

a) Potongan harga

Untuk menarik peminat beli, produk UMKM cenderung diberikan potongan harga terutama pada saat produk pertama kali masuk di Giant Ekstra Bintaro untuk dapat memiliki peminat para konsumen untuk dapat mencoba produk UMKM tersebut dan mengikuti program miller untuk mengikuti promosi mingguan dari Giant Ekstra.

b) Kesepakatan harga kemasan Kesepakatan harga kemasan ini adalah pemberian bonus kemasan, satu tambahan ekstra produk diberikan gratis saat produk dibeli pada harga tetap. Hanya berlaku untuk produk reguler saja contoh membeli sabun dapat shampo dan tidak berlaku untuk produk UMKM.

c) Kupon

Giant Ekstra Bintaro tidak melakukan pembagian kupon kepada para pembelinya untuk produk UKM.

d) Kontes dan undian

Giant Ekstra Bintaro melakukan lomba mewarnai di beberapa event, untuk menguatkan brandawarness Giant Ekstra Bintaro Sektor 7 agar lebih dikenal dan dekat dengan para pelanggannya, sehingga semua produk yang dijualnya termasuk produk UKM ikut merasakan manfaat dengan lebih banyaknya pengunjung yang datang.

e) Premium

Strategi Premium, tidak berlaku untuk produk UMKM yaitu memberikan tambahan hadiah gratis atau bonus produk lainnya

f) Sampel

Untuk produk UKM kategori sayuran telah dilakukan teknis strategi sampel contohnya event demo masak untuk sayuran edamame dan tahu yun-yi untuk memberitahukan cara mengolah dan khasiat dari mengkonsumsinya.

g) Promosi penjualan bisnis ke bisnis 
Produk UKM untuk ikut serta dalam kegiatan promosi berjenis miller yang dikenakan biaya, namun lebih kecil bila dibandingkan produk reguler/supplier besar lainnya.

h) POP Displays

Supplier produk UKM memberikan unit tampilan titik pembelian (point of purchasePOP displays) secara gratis kepada pengecer dalam rangka mempromosikan produknya. Contohnya POP yang berbentuk kotak untuk menyimpan dan menyusunan buah pisang diatasnya. Hal ini dilakukan dengan tujuan utama agar produk terlihat secara jelas oleh konsumen dan menimbulkan daya tarik para pembeli.

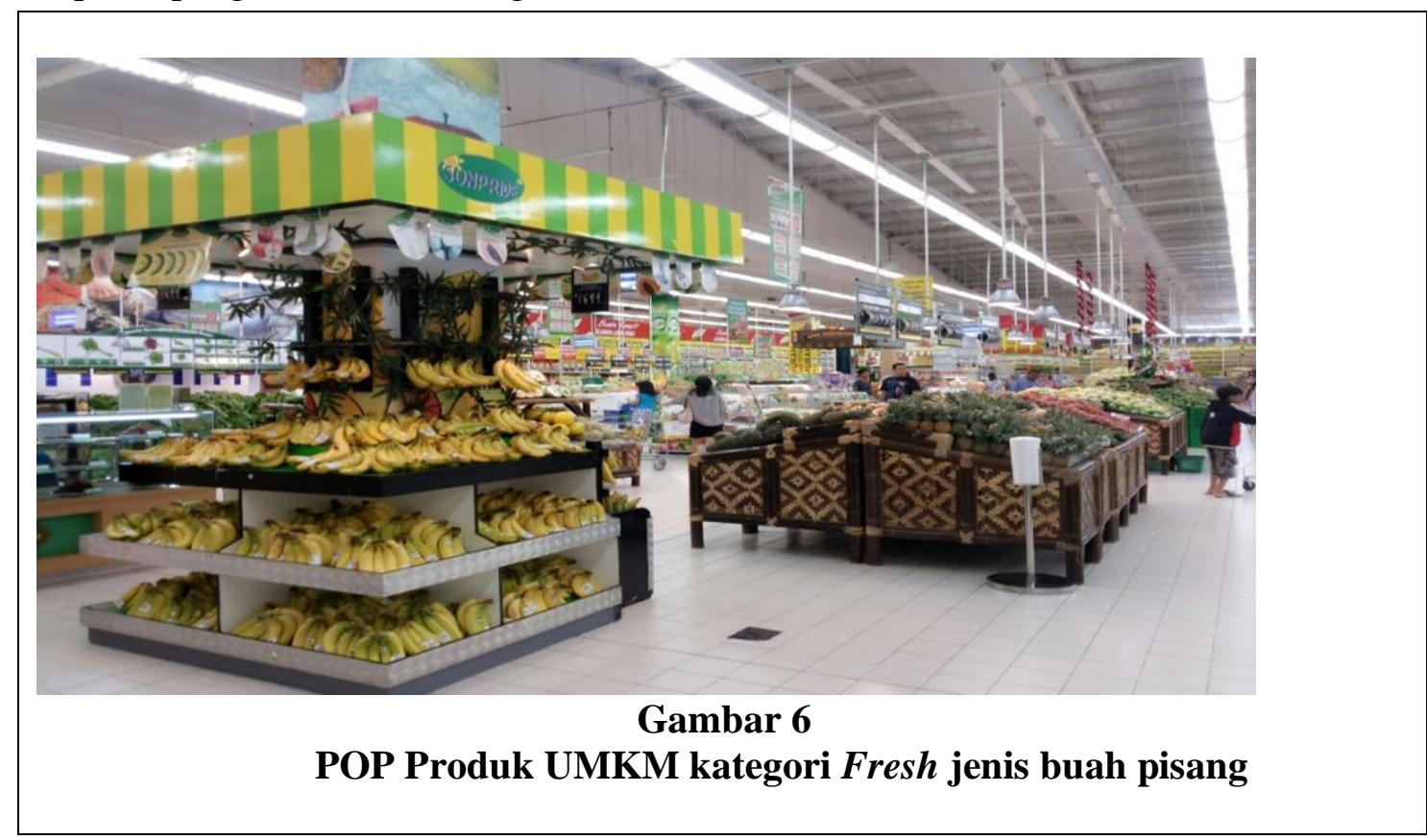

i) Kontes penjualan

Supplier produk UMKM tidak melakukan kontes penjualan yaitu memberikan hadiah (contoh uang tunai atau tiket liburan) kepada pihak Giant Ekstra Bintaro Sektor 7 Tangerang Selatan jika berhasil meningkatkan kuota penjualan

j) Pameran dagang
Terdapat produk UMKM yang mengikuti bazaar dilahan parkiran Giant seperti produk buah-buahan mangga.. Pameran dagang ini hanya untuk meningkatkan kuota penjualan, dengan tidak terlepas adanya pemberian potongan harga didalamnya.

k) Pertemuan tenaga penjual 
Pihak Giant Ekstra Bintaro Sektor 7 Tangerang Selatan tidak melakukan ini, karena sudah banyak menerima produsen semua produk, baik reguler maupun UKM.

1) Dorongan uang

Pihak Giant tidak menerima insentif atau dorongan uang (spiffs) dari produk UKM atas keberhasilannya menjual dan membangun Kesadaran merek produk.

\section{Hubungan Masyarakat \\ Relation)}

(Public

Kegiatan CSR untuk produk UMKM adalah dengan cara mendatangi koperasikoperasi atau supplier UMKM secara langsung dan memberikan penyuluhan mengenai bagaimana cara mengenalkan produk kepada konsumen dalam membangun Kesadaran merek. Jika ada UMKM yang dinilai memiliki potensi dan berkembang, maka pihak Giant Ekstra Bintaro tidak sungkan untuk menggandengnya, memberikan penyuluhan rutin, memberikan tempat display yang bagus atau bahkan mengadakan acara tertentu dengan mengundang berbagai supplier UMKM agar dapat dikenal oleh masyarakat banyak. Kegiatan-kegiatan yang terkait dengan hubungan masyarakat ini adalah:

a. Hubungan Pers

Giant Ekstra Bintaro memberikan liputan berita hasil kunjungan atau observasi kepada pihak UKM agar bisa mampu bersaing dengan produk luar, sehingga dapat memberikan efek meningkatnya penjualan dan pihak Giant Ekstra Bintaro Sektor 7 Tangerang Selatan dapat mendapatkan margin lebih banyak dari penjualan tersebut. Hasil liputan ini berada disetiap majalah Hero group, namun tidak diberikan kolom khusus mengulas mengenai produk UKM namun sama bergabung dengan berita lainnya. Liputan buletin atas produk UKM ini memberikan informasi tentang pelatihan yang diadakan Pihak Giant Ekstra Bintaro bertujuan untuk memperbaiki kualitas produk agar dapat menumbuhkan kepercayaan konsumen bahwa kualitas produk UKM tersebut bagus sehingga menumbuhkan kesadaran merek (Kesadaran merek) dalam pemahaman para konsumennya.

b. Publisitas produk

Yaitu melakukan pemberitahuan kepada konsumen dengan cara melakukan bzar, memasang iklan, dan memberikan miller kepada para pengunjung Giant Ekstra Bintaro Sektor 7 Tangerang Selatan. Terdiri dari :

1) Komunikasi korporat

Komunikasi ini mencakup komunikasi internal dan ekxternal serta teknis mempromosikan pemahaman tentang organisasi. Pihak Giant Ekstra Bintaro Sektor 7 Tangerang Selatan juga melakukan kegitan korporat ini dengan cara mengunjungi 
produsen UKM yang bergabung pada koperasi.

2) Melobi produsen UMKM yang memiliki potensi.

\section{Penjualan Personal (Personal Selling)}

Banyak supplier reguler Giant Ekstra Bintaro Sektor 7 Tangerang Selatan melakukan penjualan personal, dimana pihak supplier menyediakan pramuniaganya untuk berjualan langsung produk yang dititipkan di Giant Ekstra Bintaro Sektor dijual. Namun khusus produk ukm sendiri, hal ini belum banyak yang melakukan, karena keterbatasan dana sehingga pola penjualan langsung jarang dilakukan oleh supplier UKM. Hanya sebagian kecil, seperti contoh Supplier UKM yang telah menyediakan pramuniaga untuk berjualan langsung adalah Supplier Tahu Yun-yi dan Edamame hal ini dilakukan ketika acara icip-icip dan demo masak.

\section{Periklanan (Advertising)}

Periklanan yang dilakukan oleh Giant Ekstra Bintaro Sektor 7 Tangerang Selatan terdiri dari memuat tayangan iklan di televisi setiap hari pada pagi hari, memuat liputan berita disurat kabar kompas setiap jumat, memiliki miller sendiri untuk semua produk yang dijual dan situs resmi hero Group yang didalamnya terdapat katalog yang bisa di download langsung para konsumennya.

\section{Strategi Komunikasi Pemasaran dengan Brandawarenss Produk UMKM.}

Setelah melakukan kajian strategi komunikasi pemasaran terpadu dilapangan terhadap produk UMKM di Giant Bintaro
Ekstra, ternyata Kesadaran merek terhadap produk UKM masih sangat rendah kategori fresh dan snack masih pada tahapan tidak menyadari merek (Unaware of brand) dan lebih cenderung memilih produk karena adanya potongan harga atau murah. Maka hasil dari kajian di klasifikasikan sesuai tingkatan kesadaran merek sebagai berikut:

\section{Top of mind}

Belum ada Produk makanan UKM kategori fresh dan snack yang masuk kategori top of mind karena banyak pesaing yang lebih baik dari segi produk, kemasan dan harga, dikenal karena sering mengikuti promosi dan iklan. Merek yang telah terkenal membuat orang percaya untuk membeli karena merasa telah ada jaminan keamanan pasti dalam berbelanja.

\section{Brand recall}

Brand recall menggunakan multi respond questions yang artinya memberikan jawaban tanpa dibantu. Belum ada produk makanan UKM kategori fresh dan snack masuk kategori ini, karena banyaknya produk regular yang sejenis tersedia, sehingga mengalahkan produk UKM. Hal ini akibat dari efek, tidak banyak mengikuti kegiatan pemasaran di Giant Ekstra Bintaro Sektor 7 Tangerang Selatan.

\section{Brand recognition}

Brand recognation adalah mengenal merek yaitu tingkat kesadaran responden terhadap suatu merek diukur dengan diberikan bantuan seperti ciri-ciri suatu produk. Belum ada produk makanan UKM kategori fresh dan snack yang masuk dalam kategori top of mind ini. 
Hal ini disebabkan karena produk UKM kurang memiliki cirri khas dan cita rasa khas sebagai pembeda dengan produk regular lainnya.

\section{Unaware of a brand}

Merupakan tingkat yang paling rendah dari piramida Kesadaran merek dimana konsumen tidak menyadari akan adanya suatu merek. Semua produk makanan UKM kategori fresh dan snack termasuk pada unaware of brand dibuktitkan dengan hasil korespodensi para pelanggan yang lebih cenderung membeli produk kebutuhan pokok hanya berdasarkan harga murah dan potongan harga dengan kualitas baik.

\section{Membangun Kesadaran merek produk makanan UMKM kategori fresh dan snack dengan teori kendali organisasi}

Giant Ekstra Bintaro Sektor 7 Tangerang Selatan memiliki struktur organisasi untuk melaksanakan kegiatan operasional perusahaannya yaitu menjual berbagai produk barang dan makanan kebutuhan pokok sehari-hari. Organisasi yang dibentuk memiliki fungsi dan tanggungjawab pekerjaan masing-masing.

Terdapat empat cara kendali organisasi Giant Ekstra Bintaro Sektor 7 Tangerang Selatan sesuai teori kendali organisasi sebagai berikut:

\section{Kendali sederhana}

Setiap karyawan yang bekerja di Giant Ekstra Bintaro dikendalikan dengan tugas dan pengawasan langsung dari para atasan yang bersangkutan, untuk memastikan setiap pegawai bekerja sesuai job desk yang telah diatur dalam standar operasional perusahaan.

2. Kendali teknis

Giant Ekstra Bintaro memfasilitasi para pegawai dengan telepon genggam/walky talky. Dengan adanya fasilitas telepon genggam ini memudahkan pelaksanaan pekerjaan di toko ataupun kantor pusa. Contohnya: dalam pengisian suatu produk (refill) dibutuhkan komunikasi antar pegawai gudang dengan penjaga stand, hal ini dilakukan rutin setiap hari untuk menghindari kekosongan barang di rak yang dapat mengakibatkan pembatalan pembelian dari konsumen.

3. Birokrasi yang merupakan penggunaan prosedur organisasi dan aturan-aturan formal

Setiap pegawai Giant Ekstra Bintaro diberikan buku panduan peraturan perusahaan yang menjelaskan mengenai kebijakan perusahaan. Setiap minggu diadakan meeting point disetiap divisi untuk mengawasi berjalannya semua prosedur setiap minggunya. Jika ada masalah, maka akan bisa langsung dicarikan solusinya agar tidak berlarut-larut.

4. Kendali konsertif

Giant Ekstra Bintaro memiliki struktur organisasi kompleks yang mengatur semua bagian terkait dalam kegiatan operasional. Peraturan dan kebijakan Perusahaan jelas yang tertuang dalam Standar Operasional Perusahaan (SOP), Peraturan Perusahaan (PP), Prosedur yang telah memiliki sertifikat 
ISO, didukung dengan program sistem pencatatan dimulai dari front desk sampai dengan buku besar, perekrutan pegawai dengan sistem seleksi dan pemberian pelatihan serta training membuat semua berjalan sesuai aturan dan tujuan yang diharapkan. Untuk semua produk yang masuk di Giant Ekstra Bintaro Sektor 7 Tangerang Selatan juga telah dilakukan quality control sebelum menerimanya, dengan melihat BPOM, kelayakan konsumsi untuk dimakan, kejelasan komposisi makanan dan sampai pengemasan untuk memberikan kepuasan berbelanja para konsumennya, dimana kepuasaan konsumen tercapai agar terus berbelanja di Giant Ekstra Bintaro Sektor 7 Tangerang Selatan merupakan tujuan dari komunikasi pemasaran.

\section{SIMPULAN}

Giant Ekstra telah menerapkan strategi komunikasi pemasaran terpadu terhadap semua produk, termasuk produk UMKM, dan tidak membedakannya, hal ini membantu mengenalkan produk dan membangun kesadaran merek atas produk UMKM tersebut. Kesadaran merek atas produk UMKM belum terwujud di Giant Ekstra Bintaro Sektor 7 Tangerang Selatan, hal ini terkait dengan kalah saing dengan produk reguler/impor lainnya, dari segi barang itu sendiri dan belum mengikuti semua promosi yang diadakan pihak Giant karena terkendala dana.

\section{UCAPAN TERIMA KASIH}

Puji dan syukur kepada Allah SWT yang telah memberikan kemudahan, kemampuan dan atas segala rahmat karunia-Nya dalam menyelesaikan penelitian ini. Terimakasih kepada orangtua atas dukungan yang diberikan, beserta kepada pihak Giant Ekstra Bintaro sektor 7 Tangerang selatan yang terlibat dalam penelitian ini, yaitu Bapak Syogi selaku HRD PT Hero Supermarket yang memberikan kesempatan untuk melakukan penelitian di Giant Ekstra, Ibu Nafisyah selaku Humas yang telah membantu penulis mendapatkan informasi dan memberikan arahan, Ibu Linda selaku Manager pemasaran yang telah memberikan informasi dan Bapak Samuel selaku Manager Merchandising yang bersedia meluangkan waktunya untuk melakukan wawancara dalam proses penelitian ini.

\section{DAFTAR PUSTAKA}

Aaker, David. A. (1997). Manajemen Ekuitas Merek. Jakarta: Penerbit Mitra Utama

Asa Robika, Aulia. (2016). Perencanaan Strategi pemasaran dengan metode multidimensional Scalling dan Quality Function Deployment .Jurnal Teknik Industri. Vol.17 No. 1 Tahun 2016

Effendy, Onong U. (1998). Hubungan Masyarakat: Suatu Studi Komunikologis. Edisi Revisi. Bandung: Remaja Rosdakarya.

Fildzah, annisa nurul. (2018). Analisis Strategi Promosi pada UMKM Social Enterprise (Studi Kasus Pascorner Cafe and Gallery). Jurnal Komunikasi. e-ISSN: 2548-7647

Hermawan, Agus. (2012). Komunikasi Pemasaran. Jakarta: Penerbit Erlangga. 
Kotler,P. (2000). Manajemen Pemasaran. Edisi 10. PT. Prenhallindo. Jakarta.

Kotler, Philip, Gary Armstrong. (2001). Prinsip-prinsip Pemasaran Jilid 2, Jakarta : Penerbit Erlangga.

Kotler, Philip, Gary Armstrong. (2004). DasarDasar Pemasaran Jilid 2. (Damos Sihombing. Alih Bahasa). Jakarta: Penerbit Erlangga.

Kotler, Philip \& Kevin Lane Keller, (2008). Manajemen Pemasaran. Jilid Satu, Edisi Keduabelas, Cetakan Ketiga. Penerbit Indeks.

Moleong, Lexy. (2002). Metodologi Penelitian Kualitatif. Bandung:PT. Remaja Rosdakarya.

Monigir, Rivo. (2016). Penerapan strategi pemasaran untuk mencapai keunggulan bersaing (Studi kasus pada multi market Ranotana Manado). ISSN 2303-1174 Vol.4 No. 4 Tahun 2016

Philip Kotler (1994), Marketing Management; Analysis, Planning,Implementation and Control, Eighth Edition, 1994.

Ruslan, Rosady. (2003). Metode Penelitian PR Dan Komunikasi. Jakarta: PT. Raja Grasindo Persada.

Setiadi, Nugroho J. (2003). Perilaku Konsumen: Konsep dan Implikasi untuk Strategi dan Penelitian Pemasaran. Jakarta: Kencana Prenada Media Group.

Silaninghsih, P Utami. (2018). Pengaruh marketing mix terhadap minat beli konsumen pada usaha Mikro Kecil dan Menengah (UMKM) Produk Olahan Makanan Ringan. Jurnal Sosial Humaniora.e- ISSN: 2550-0236.Vol. 9 No.2 Tahun 2018

Soemanagara, Rizky. (2006). Strategic Marketing Communications. Bandung: PT. Alfabeta.

Surya, Aristo. (2009). Analisis persepsi konsumen pada aplikasi bauran pemasaran serta hubungannya terhadap loyalitas konsumen (studi kasus pada hypermarket cabang kelapa gading). Journal of business strategy and execution 2 tahun 2009 13-39.

Undang-Undang No.20 tahun 2008 tanggal 4 Juli 2008 tentang Usaha Mikro, Kecil dan Menengah.

www.hero.co.id 